\title{
Essential terms of the contract of carriage of goods
}

\author{
Elvir Akhmetshin ${ }^{1}$ and Kseniya Kovalenko ${ }^{2 *}$ \\ ${ }^{1}$ Kazan Federal University, Elabuga Institute of KFU, Elabuga, Russia \\ ${ }^{2}$ Altai State University, Barnaul, Russia
}

\begin{abstract}
The specifics of the contract of carriage of goods and its difference from other types of contracts used in the sale of goods and services are considered. Application of the contract of carriage of goods for the regulation of large-scale and long-term relations, and also relations between the branches of the economy and the regions of the country are considered. This is of practical importance and is necessary due to the fact that the specifically dedicated norms are applied to each contract along with the norms common to all sales contracts. At the same time, the legal characteristic of economic contract depends not only on the name assigned to it by the parties but also on those rights and obligations that the parties have determined in the contract. However, the functions performed and the role of each of the types of transport contracts cannot be unambiguous. In the article, the factors affecting the transport service of international business transactions are considered.
\end{abstract}

\section{Introduction}

Studies have shown that legal relationship for the carriage of goods in the legal literature was considered as consisting of two obligations - independent (arising one from the transportation plan and the other from the contract of carriage) or relatively independent, forming a single legal relationship (obligation) associated with the carriage of goods. The first obligation is the subject of the actions of the parties (the carrier and the sender) for the supply of transportation means for loading and, accordingly, the presentation of goods for transportation and their loading into conveyances. The subject matter of the second obligation is the actions of the carrier for the transport of goods to the destination and issuance to the recipient or other authorized person, as well as the sender's payment of the established freight charges [1].

When considering the basic elements of the legal relationship for the carriage of goods, the specified relationship should be regarded as a single obligation associated with the carriage of goods, as was done in the legal literature.

Participants in the obligation to transport goods recognized, as follows from the very legislative definition of the contract of carriage, the consignor, the carrier and the consignee.

\footnotetext{
* Corresponding author: kovalenko1288@mail.ru
} 
The carriers were mainly specialized organizations (public transport), which were part of the relevant transport ministries and departments.

In case of non-fulfilment by the parties of contracts mediating the whole process of transporting goods by road, their duties can be called improper performance, which is the basis for the onset of liability for them, provided for transport legislation. When determining the true role of the contract in the formation of the content of the obligation of freight transportation, it is necessary to take into account the specifics of the regulation of the relations of the carriage of goods and the fact that the contract of carriage of goods is real. You cannot exaggerate the role of the element of the agreement in the formation of conditions, the content of which is formed by the parties when concluding the contract of carriage of goods. Nevertheless, they determine the rights and obligations of the parties in the transportation of goods and determine, respectively, the legislative role of the contract of carriage of goods. The actual role of the contract of freight transportation is that it defines the participants of the obligation at the stage of its development after the conclusion of the contract - the carrier, the consignor and the consignee, and also that it is the legal form of securing the parties established by the agreement in accordance with the regulatory requirements for the conditions of carriage of the accepted carrier of cargo.

\section{Methods}

The current research uses the methods of observation, comparative legal studies, formal logic, description, and interpretation. The length of the network of public roads in Russia is $1,396,000 \mathrm{~km}, 50,800 \mathrm{~km}$ of which have the status of federal highways, $929 \mathrm{~km}$ - highway status. The length of roads with a hard surface is $984,000 \mathrm{~km}$.

Road transport has the highest figures for the quantitative transport of goods and passengers. In 2014, it accounted for $68 \%$ of all transported goods and $60 \%$ of all passengers. But unlike railway transport, the distance of cargo transportation by road is not very large, on average it is $44.4 \mathrm{~km}$ (Figure 1).

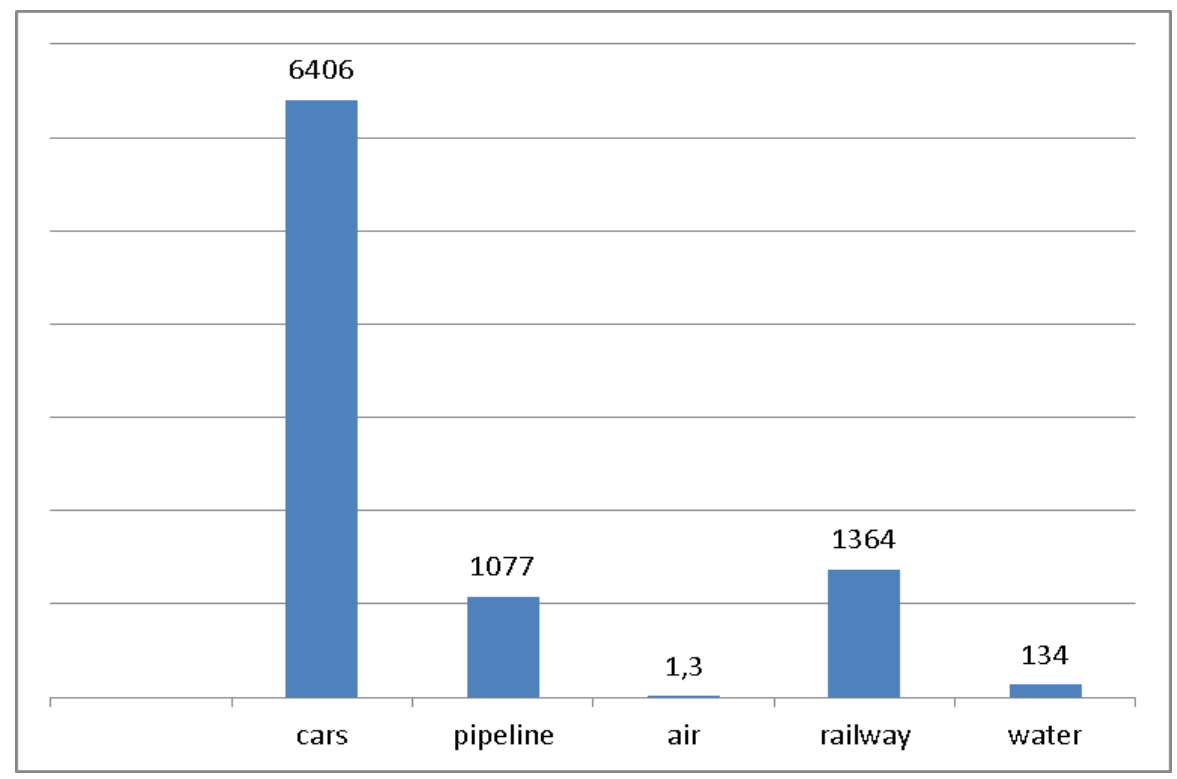

Fig. 1. Transportation of goods by type of transport, million tons 
In terms of turnover, road transport occupies the third place after pipeline transport and Russian Railways, which is understandable - the cargo carrying capacity of cars is not large in compare with those listed, nevertheless, it is the road hauliers that deliver us the goods of daily demand and not only them. Motor transport is called "last mile" transport, but it is not quite so: the whole harvest is exported by cars, the cars not only take out cargo from Russian Railways, Avia and the Rivers-Sea but also deliver them there for further transportation. So when they say that Russian Railways from this year and Avia or collective farmers use road transport excises for gasoline (at the same time, they do not use roads), it means only one thing - people do not understand that the transport system of Russia is not only an interconnected complex but also interdependent. Standing in the field stations, stations, ports without attaching roads are meaningless, and the rails do not lead to the fields.

\section{Results}

International transport operations among all the variety of business operations performed in foreign markets are more complicated than those performed on the domestic market. This is due to both large distances and the involvement of more subjects in international transport, the presence of specific factors and conditions for the transport of goods (Table 1). Therefore, it is very important to consider the features of the contract of carriage of goods.

Table 1. Factors affecting the transport service of international business transactions.

\begin{tabular}{|c|c|c|}
\hline & Group & Factors \\
\hline 1. & Economic & $\begin{array}{l}\text { Membership in international transport organizations and } \\
\text { implementation of international agreements in the field of transport } \\
\text { - The state system of control over the activity of transport enterprises } \\
\text { and entrepreneurs in the field of international transport and foreign } \\
\text { carriers in the territory of the countries } \\
\text { - Protection and support of the activities of transport enterprises and } \\
\text { entrepreneurs in foreign markets } \\
- \text { Creation of necessary conditions for the development of the } \\
\text { international transport infrastructure }\end{array}$ \\
\hline 2. & $\begin{array}{l}\text { Political and } \\
\text { legal }\end{array}$ & $\begin{array}{l}\text { - The nature of the relationship of states (including "transit"), affecting } \\
\text { foreign trade activities } \\
\text { - Transport and trade policies of countries, unions, international } \\
\text { associations involved in the transport of business operations } \\
\text { - State economic and commercial-legal regulation of transport activities } \\
\text { - State assistance to the formation and functioning of transport services } \\
\text { markets }\end{array}$ \\
\hline 3. & Technological & $\begin{array}{l}\text { - Level of scientific and technological progress in certain types of } \\
\text { transport } \\
\text { - Level of navigation services } \\
\text { - The level of development of individual progressive transport and } \\
\text { technological systems } \\
\text { - Regularity and quality of transport services } \\
\text { - Technical and operational characteristics of vehicles, handling } \\
\text { equipment } \\
\text { - Transport characteristics of transported goods } \\
\text { - Reliability of operation of technical facilities and safety of movement } \\
\text { of vehicles on certain modes of transport } \\
\text { - Control over the implementation of regulatory requirements for the } \\
\text { operation of vehicles } \\
- \text { Qualification of personnel serving the transport equipment and } \\
\text { responsible for its condition and operation }\end{array}$ \\
\hline
\end{tabular}




\begin{tabular}{|l|l|l|}
\hline \multirow{3}{*}{ Natural } & $\begin{array}{l}\text { - Natural and climatic features of countries and regions in which the } \\
\text { transport provision of foreign economic activity is carried out } \\
- \text { The degree of development of certain types of public transport, } \\
\text { depending on the geographical features of the country, the size of its } \\
\text { territory, the historical conditions for the formation of the transport } \\
\text { network } \\
\text { - Seasonality of transportation and operation of certain types of public } \\
\text { transport } \\
\text { - State of the meteorological situation }\end{array}$ \\
\hline
\end{tabular}

Under the contract of carriage of cargo, the carrier undertakes to deliver the cargo entrusted to him by the consignor to the point of destination and extradite him to the person entitled to receive the goods, and the consignor undertakes to pay for the carriage of cargo the established fee (Clause 1, Article 785 of the Civil Code of the PF).

The legal nature of the contract of carriage of goods is:

-real;

-competitive;

-sided.

However, in some cases, this contract may be consensual. The contract of carriage is considered consensual when the carrier undertakes to provide vehicles before the delivery of goods for carriage. For example, in maritime transport, a contract of carriage (called a charter contract or a charter) is consensual [2].

The contract of carriage of goods is a fixed-term contract, as the term of its validity is determined by the deadline for fulfilling the obligation to transport (Article 792 of the Civil Code).

In regulating transport relations, great importance is given to sectoral regulatory acts. General conditions for the carriage of goods and liability of the parties are determined in the contract, unless otherwise provided by the charters and codes, other laws and rules issued in accordance with them (clause 2 of Article 784 of the Civil Code of the Russian Federation) [3-6].

As a rule, a single written document is not necessary for a contract of carriage. The conclusion of a contract for the carriage of goods is confirmed by the compilation and delivery of a consignment note (a bill of lading or another document for cargo provided for in the relevant transport charter or code) to the sender (paragraph 2 of Article 785 of the Civil Code of the Russian Federation) [3-6].

If the law or other normative act does not specify the amount of freight charges, then the parties are entitled independently in the contract to determine the cost of transportation services (Clause 1, Article 790 of the Civil Code of the Russian Federation) [3-6].

The contract will be considered concluded if an agreement has been reached between the parties on all material terms of the contract (Article 432 of the Civil Code of the Russian Federation).

Essential conditions for specific types of transportation are determined by charters and codes, other laws and rules issued in accordance with them (clause 2, Article 784 of the Civil Code of the Russian Federation) [7].

Depending on the type of transport used to transport goods, the transportations are divided into railway, sea, river, air, and automobile. This classification is due to the fact that the relations associated with the carriage of goods are regulated by law, which applies to the appropriate mode of transport. There are local, direct and direct multimodal transportations. Local calls are transport within one transport enterprise (railway, shipping company, etc.).

Direct transportation - one document involves several enterprises of the same mode of transport. So, a direct railroad will make transportation by one document (a waybill) from 
Moscow to Irkutsk, since the cargo in this case is transported by several railway companies (Moscow, Sverdlovsk, Irkutsk and other roads).

A direct multimodal transport is considered to be transportation when the goods are transported by different enterprises of several modes of transport on the basis of one document. An example of such transportation can be the delivery of cargo from Moscow to Astrakhan by rail, and from Astrakhan to one of the ports on the Caspian Sea (in Russia) by sea [8]. Maritime transport distinguishes between small cabotage, large cabotage, and overseas traffic. Small cabotage means the transportation of goods between Russian ports of the same sea. Greater cabotage includes cargo shipments between Russian ports of different seas, even if the ship is passing through foreign waters. Transportation from Russian ports to foreign ports or vice versa is recognized as transportation in a foreign communication [9].

The Air Code does not subdivide transport into separate types, but contains some special rules for international transport (Chapter XI VC) [3-5].

International flights of aircraft are performed on the basis of international agreements of the Russian Federation or permits issued in the manner established by the Government of the Russian Federation. The rules of international flights of aircraft and other information necessary for the implementation of international air services are published in the Aeronautical Information Publication of the Russian Federation.

In road transport, transportation is divided into urban, suburban, intercity, and international. The contract of carriage of goods is of a public nature (clause 2 of Article 789 of the Civil Code of the Russian Federation) [10].

The content of the contract of carriage of the goods is the rights and obligations of the parties. Loading and unloading of cargo are carried out by the transport organization or the sender (recipient) in the manner provided by the contract and in compliance with the rules of transport legislation (clause 2, article 791 of the Civil Code of the Russian Federation) [11].

Duties for loading and unloading are distributed among the participants of the obligation of carriage, depending on the place of loading. The carrier is obliged to submit to the consignor of the cargo serviceable vehicles in a condition suitable for the carriage of the corresponding cargo for loading within the time period established by the application (order) received from it, the contract of carriage, or the agreement on the organization of transportation. The consignor has the right to refuse from the submitted vehicles which are not suitable for the transportation of the corresponding cargo.

Loading (unloading) of cargo is carried out by the transport organization or the sender (recipient) in the manner provided by the contract and in compliance with the provisions established by the transport charters and codes and issued in accordance with the rules [12].

Cargo delivery is the main duty of the carrier. The carrier is obliged to deliver the goods to the point of destination within the time limits specified in the procedure provided for by the transport charters and codes, and in the absence of such terms - within a reasonable time [13-17]. The introduction of freight charges (freight on maritime transport) and other payments is the most important duty of the consignor. Its size is established by agreement of the parties, unless otherwise established by the transport legislation (Article 790 of the Civil Code of the Russian Federation) [18]. An exception is made with respect to public transport, where the freight fee takes the form of a solid tariff approved in the manner prescribed by the transport charters and codes. The size of this tariff is determined by the federal executive bodies of the subjects of the Russian Federation [19-22].

The freight fee should normally be paid by the consignor at the conclusion of the contract of carriage. It is also possible to transfer the payment obligation to the recipient.

The carrier is entitled to withhold the cargo. The carrier is responsible for the safety of the cargo from the moment it is accepted for transportation and until it is issued to the 
recipient [23-24]. Execution of operations for the delivery and acceptance of goods completes the performance of the contract of carriage.

\section{Conclusions}

In conclusion, the most common case of inadequate implementation of the obligations under review is the failure to meet the deadlines in the process transportation both on the part of the carrier (delay in the delivery of the vehicle to the loading point, delay in the delivery of the goods) and on the part of the recipient (the idle time of the vehicle). The violation of the established time limits, as a rule, entails the application of fairly strict sanctions against the defective party. This is due to the fact that in modern conditions, not only the fact of the transportation carried out but also the time spent on its implementation. It is the contractual conditions that model the behavior of the parties to the treaty and their rights and duties are defined. Rights and obligations arise not from the legal acts of transport regulations and codes of transportation rules, but from a contract, regardless of whether the given condition is imperatively definite or prescriptive, i.e. regardless of the degree of independence of the parties in the formation of contractual conditions.

Receipt of cargo must be duly executed, which is covered by the concept of crediting documents or redemption of goods and is certified accordingly on the waybill (bill of lading). In order to fulfill this obligation, the recipient must be notified of the arrival of the goods in the manner and within the time limits established in the appropriate mode of transport. Only road transport, which ensures the delivery of cargo directly to the warehouse of the recipient, does not always need to notify the latter of the arrival of the goods. The consignee is obliged to take (take out) the cargo on time. If this condition is violated, he must pay a fee for storing the goods, which can be increased several times because of his fault.

Upon expiration of the established storage terms, unclaimed goods are subject to sale in the established manner. The non-documented goods, i.e. the goods arriving without accompanying documents, are also subject to sale.

\section{References}

1. S.S. Alekseev. Civil liability for failure to fulfill the plan railway transportation of goods (Moscow, 1959).

2. M.I. Braginsky, V.V. Vitryansky. Contract Law. Book 4: Treaties on transportation, towing, transport expedition and other services in the field of transport. (Moscow, 2004).

3. URL: http://www.consultant.ru/cons/cgi/online.cgi?base $=$ LAW \&n= $294690 \& d s t=$ 429496

7295\&cacheid $=6$ EAAB88D342A76CCFB97B0D5658E0426\&mode $=$ rubr\&req $=$ doc \&rnd=DA3F551662AB8B78C228FDF1333E99EF\#07428796849859929.

4. URL: http://www.consultant.ru/cons/cgi/online.cgi?base $=$ LAW\&n= 294690\&dst= 429496

7295\&cacheid $=6$ EAAB88D342A76CCFB97B0D5658E0426\&mode $=$ rubr\&req $=\mathrm{doc}$ \&rnd=DA3F551662AB8B78C228FDF1333E99EF\#07428796849859929.

5. URL: http://www.consultant.ru/cons/cgi/online.cgi?req=doc\&ts= 1605483 885048698168553918353\&cacheid=10D9778BDC07F4FF733CA8CBE97DF747\&m ode $=$ splus \&base $=$ LAW \&n=280491\&rnd=47F6DBB672FDF74D37F42EB237627B4.

6. URL: http://www.consultant.ru/document/cons_doc_LAW_14121. 
7. I.A. Reshetnik. Civil-law regulation of leasing in the Russian Federation (Perm, 1998)

8. V.Vitryansky. Economy and law, 2 (2010).

9. V.V. Vitryansky. Economy and Right, 3 (2001)

10. G.S. Gurevich. On the issue of the legal nature of the contract of carriage of goods . Scientific notes, 67 (1964)

11. M.I. Braginsky, V.V. Vitriansky. Contract law. Book One: General Provisions. (Moscow, 2000)

12. K.E. Kovalenko. Some aspects of reasonableness in the law. World Applied Sciences Journal, 7 (2014)

13. A.M. Simonenko, O.N. Troitskaya. Commentary to the Air Code of the Russian Federation (article-by-article) (Moscow, 2007)

14. Order of the Ministry of Transport of the Russian Federation of 02.07.2007 № 85 "On Approval of the Rules for the State Registration of Civil Aircraft of the Russian Federation". Bulletin of Normative Acts of Federal Executive Bodies, 41 (2007)

15. N.V. Vartanyan. Transport Law, 3 (2009)

16. Order of the Minister of Defense of the Russian Federation of 28.11.2002 No. 460 "On Approval of Federal Aviation Rules for State Registration of State Aircraft". Bulletin of Normative Acts of Federal Executive Bodies, 20 (2003).

17. Order of the Ministry of Transport of the Russian Federation No. 132 of May 16, 2003 "On Approval of Federal Aviation Regulations" A copy of an aircraft. Requirements and certification procedures "(2003)

18. Decree of the Government of the Russian Federation No. 766 of September 12, 2011 "On admission to operation of state aircraft". SZ RF, 38 (2011)

19. M.P. Bardina, B.A. Bulaevsky, N.G. Vilkova. Commentary on the Civil Code of the Russian Federation (Moscow, 2010).

20. V.D. Bordunov. International Air Law (Moscow, 2007).

21. M.K. Aleksandrov-Dolnik. Disputes arising from the legal relationships of the parties in railway freight operations (Moscow, 1955).

22. V. V. Vitryansky Contract of carriage (Moscow, 2001).

23. I. Degtyarev. Without an application there is no transportation. Ezh-Lawyer, 32 (2001)

24. V.A. Egiazarov. Transport Law: A Textbook (Moscow, 2004) 